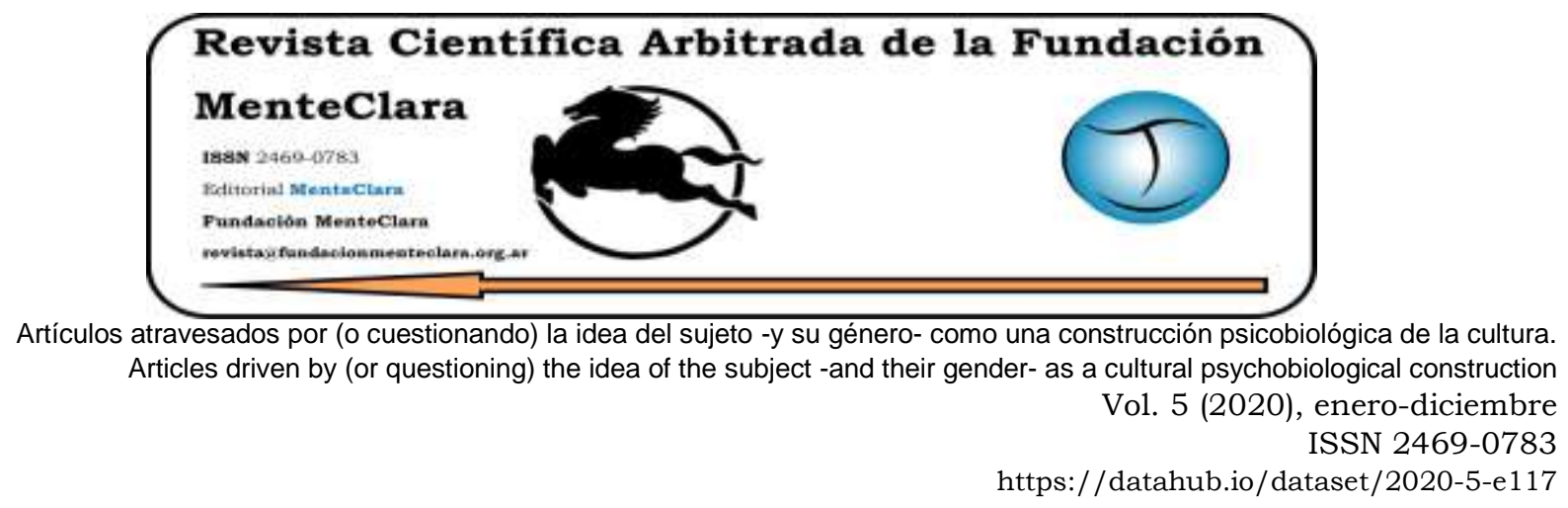

\title{
FEMINIST HISTORIOGRAPHY WITH SPECIAL REFERENCE OF PANDITA RAMABAI AND TARABAI SHINDE
}

\author{
HISTORIOGRAFÍA FEMINISTA CON REFERENCIA ESPECIAL DE PANDITA \\ RAMABAI Y TARABAI SHINDE
}

Swati Rajan swatipungaliya@gmail.com

Dept. of History Tikaram Jagannath Arts, Commerce and Science College, Khadki, Pune, Maharashtra, India

Cómo citar este artículo / Citation: Rajan S. (2020). "Feminist Historiography with special reference of Pandita Ramabai and Tarabai Shinde". Revista Cientifica Arbitrada de la Fundación MenteClara, Vol. 5 (117).

DOI: https://doi.org/10.32351/rca.v5.117

Copyright: (C) 2020 RCAFMC. Este artículo de acceso abierto es distribuido bajo los términos de la licencia Creative Commons Attribution 4.0 International License (CC BY 4.0). Recibido: 20/11/2019. Aceptado: 25/11/2019 Publicación online: 06/01/2020

Conflicto de intereses: None to declare.

\begin{abstract}
In colonial Maharashtra women tried to converse with themselves and the society through biographies, autobiographies, articles in newspapers, journals and they even wrote books, trying to discuss women's issues that arose from the patriarchal system of society at the time. They criticized social customs and blind faith in religion pertaining women, very intensely. Their writings were theoretical and visionary, and stood out creating a baseline for feminist historiography; here my efforts are to interpret their writings from that point of view. The first part of this paper discusses the efforts of feminist historiography as a whole and the second part is based on the book, 'The High Caste Hindu Woman' and 'Stri-Purush Tulana' by Pandita Ramabai and Tarabai Shinde respectively.
\end{abstract}




\section{Resumen}

En el Maharashtra colonial, las mujeres intentaron conversar con ellas mismas y con la sociedad a través de biografias, autobiografias, artículos en periódicos, revistas e incluso escribieron libros, tratando de discutir los problemas de las mujeres que surgieron del sistema patriarcal de la sociedad en ese momento. Criticaron muy intensamente las costumbres sociales y la fe ciega en la religión de las mujeres. Sus escritos fueron teóricos y visionarios, y se destacaron creando una línea de base para la historiografia feminista; Aquí mis esfuerzos son para interpretar sus escritos desde ese punto de vista. La primera parte de este documento discute los esfuerzos de la historiografia feminista en su conjunto y la segunda parte se basa en el libro "La mujer hindú de la casta alta" y "Stri-Purush Tulana" de Pandita Ramabai y Tarabai Shinde, respectivamente.

Keywords: Feminism; Historiography; Women; Colonial Maharashtra

Palabras Claves: Feminismo; Historiografia; Mujeres; Maharashtra Colonial 


\section{Hypothesis}

In this paper I try to explore the writings of nineteenth century women and the possibility of linkages they may have with today's feminist movement as these writings show the beginnings of many of the values we see amalgamate with feminism today. The historiography we see today is built largely through a chauvinistic perspective and illustrates history through the mindset of a patriarchal system. This is an effort to understand women's contribution in the evolution of feminism even though this word didn't exist at the time. Women were cautious witnesses to their changing position in colonial Maharashtra and were also part of the efforts taken by the reformers to improve the condition of deprived and victimized women. Pandita Ramabai and Tarabai Shinde criticized the traditional value system which was imposed on women forcefully and both were initially attached with social organizations; Arya Mahila Samaj and Satyashodhak Mandal respectively.

The literary work put forward by these women was theoretical, visionary and way ahead of their time, my effort here is to interpret this through the point of view of feminist historiography. The first part of this research paper will be on an efforts of feminist historiography as a whole and second part is on these writer's book namely 'Stri-PurushTulana' and 'The High Caste Hindu Woman'.

Stri Purush Tulana (Shinde, 1882) is an essay of forty pages published in the form of a book in 1882. Initially written as a response to an article on the Vijayalaxmi case published in the Pune Vaibhav, a weekly newsletter which was known to be extremely orthodox (Tharu \& Lalita, 1993). Stri-Purush Tulana thus put forth a mature feminist argument which broadened the scope in which the composition of patriarchal society was analyzed. 
Pandita Ramabai's book 'The High Caste Hindu Woman' (Ramabai, 1887) was an empathetic narration of the suppressed and oppressed lives of upper caste Hindu women who came up with a proposal for their emancipation. Considered by Meera Kosambi as the 'an unofficial Indian Feminist Manifesto' (Kosambi, 2016) the book sold over 9,000 copies within year of being published in the United States in 1887.

\section{Feminist Historiography}

The term historiography derives two basic meanings, first, it refers to a spontaneous and self conscious approach of historical practice: 'a critical consciousness at work in the writing of history' (Chandler, 1998) In the second approach (instance), it refers to a theoretical or philosophical exercise that takes a step back from the writing of substantive history, in order to critically examine the deeper underlying conceptual models and imaginaries that inform the kind of histories, and the ways that we use and approach our histories. The term 'feminist historiography' means a theoretical meta-reflection, a constant and continuous process of reinterpretation of history, thinking analyzing and observing activities and intellectual tasks. Feminists have constituted and conceptualized histories of feminism. Feminists argue that the power relationship between men and women, between different social classes in understanding social change and to grasp conflicts, multiplicity and complex relationship of society. That leads to a reinterpretation of social movements and ideology in history and opening up new fields of enquiry. Feminism is seen as the conflict against all forms of patriarchal encroachment and aggression. Feminism as the necessary resistance to the patriarchal influence, logically then it is a theory of utopia. La Capra quotes in his book (1985) 'History and Criticism' that, 'the philosophical 
feminist historiography, intimately linked to rhetorical and ethico-political concerns and discourse' (Browne, 2013).

Feminism means challenging patriarchal influence and authority and androcentric ${ }^{1}$ norms and comparison, the field of feminist history, necessarily overlaps with the field of 'women's history'.

The historical task of recovering female pasts and making women visible in history, thereby expelling or complicating androcentric or patriarchal perspectives, is indeed a crucial feminist practice (Lerner, 1979). Feminists have identified the aspects of gender discrimination as the root cause of women's disappearing status in the hierarchical order of most of the societies. Kate Millet in her one of the critical book 'Sexual Politics' describes gender as a Personality, Structure in terms of sexual category (Millet, 1998).

\section{Indian Feminist Historiography}

To comprehend and understand the insight of feminism, it is crucial to examine that Indian Feminist Historiography is altogether different scenario. Deep rooted and painful hardship of women, the hard conflict for the acceptance for the equal status in the society, long struggle for basic human rights are some of the visible imprint of the gender discrimination and inequality in India. In the 19th century few literate women tried to overcome these issues. They expressed themselves through their writings. Indian society has always been stratified by the hierarchy within a family age, ordinal position and sex, favorable relationship. Within the society remarking caste genealogy, learning,

\footnotetext{
${ }^{1}$ Dominated by or emphasizing masculine interests or a masculine point of view - compare gaynocentric.
} 
occupation and relationship with controlling power have been protected very rigorously.

Sangari and Vaid point out the significance of feminist historiography as follows: "Feminist historiography now implies in some sense a more towards the integrated domain of cultural history". Historiography may be feminist without being exclusively, women's history. Such a historiography acknowledges that each aspect of reality is gendered, and is thus involved in questioning all that we think we know, in a sustained examination of analytical and epistemological apparatus, and in a dismantling of the ideological presuppositions of so called gender neutral methodologies. A feminist historiography rethinks historiography as a whole and discards the idea of women as something to be framed by a context, in order to be able to think of gender difference as both structuring and structured by the wide set of social relations (Sangari $\&$ Vaid, 1998). The literature written mainly by women and concerned to women is called feminist literature. Women's writing emerged in India as a new site of research and critical studies in the 1980's, as a result of feminist movement and as a consequence of growing interesting feminist historiography. Feminist historiography which consciously reflects upon the writing of history from a feminist standpoint emphasizes the importance of examining writings by women. Seemanthini Niranjana points out the significance of women's writings as follows:

"As a discursive practice, women's writing is situated within the wider cultural context of patriarchy and its structural manifestations. Despite the varying specificity of content under different modes of production, patriarchy can be described in terms of the dominance of the male and a corresponding marginalization of women. In such a circumscribing milieu, women's writing assumes importance as response to patriarchal relations within patriarchy itself. It may 
provide a unique record of the systems which shapes and contains the life stories of women" (Niranjana, 1989).

She identifies women's writing as a site of struggle which involves both dominant perceptions of social reality and the resistances to it (Niranjana, 1989). In this sense, women's writings become significant documents in the analysis of women's spaces, which demonstrate the making and remaking of these spaces while recording their resistances to the outside world. Feminist historiography, while deconstructing dominant ways of writing women's history, considers women's writing itself as history writing.

\section{The Introduction: Authors and Books}

The objective of the research paper is to demonstrate the evolution of woman space that materializes in the writings of Pandita Ramabai and Tarabai Shinde's books 'The High Caste Hindu Woman' and 'StreePurush Tulana'. This study looks at the feminist historiography of both books to trace the linkage and importance of their writing to the today's feminist agenda. In this research paper, it will be interesting to look at how, at different junctures, the dominant social sphere tried to eclipse it in different ways and how at different crossroads it spoke the language of negotiation in an attempt to appropriate this space.

I draw some instances mainly from Pandita Ramabai's book 'The High Caste Hindu Woman' and Tarabai Shinde's book 'Stri-Purush Tulana'. Their writings are based on basic expectations of adverse condition of women, then, which imposed by male dominated society. Tarabai's writing is more radical than Pandita Ramabai. This study specifically locates both writers' conscious efforts as a woman, within this tradition of resistance and strives to present, how their writings contribute to the 
women's well being through a merging of the public and the private way of life.

Pandita Ramabai and Tarabai Shinde, their experiences of life, courage to resist established social norms and religious unjust, prejudiced practices is exclusive. They had keen interest in the social upliftment of women. They were also aware of their personal space and freedom of life. In this research paper, the emphasis is to understand their writings with a view of feminist historiography. It will be interesting to look into that, how they resisted the ideological imposement of patriarchal values on women. They were both thinking about the adverse condition faced by women to get opportunities to grow themselves. Both posed logical opposition to the dominant values of the chauvinistic society or moved away from those that were excluded from its narrative; this study is thus interesting from a feminist historiography point of view.

Each woman writer was forcibly compared with her male contemporaries or judged against or in comparison with them. Therefore, women writers of every generation did not feel a collective sense of identity as 'women writers'. Pandita Ramabai and Tarabai Shinde published their work just a few years apart, with a broader view they both opined on women's discrimination and against the privileged patriarchal system. However, there doesn't seem to be evidence of them having been acquainted with each other showing that they worked as individual identities physically and ideologically putting forth similar views despite the lack of a shared institution or school of thought. Elaine Showalter similarly observes this point in her writing 'A Literature of Their Own' (1977) where she states, "... each generation of women writers had found themselves in a sense, without a history, forced to rediscover the past anew, forging again and again the consciousness of their sex. Given this perpetual disruption and also the self-hatred that has alienated women 
writers from a sense of collective identity, it does not seem possible to speak of a movement" (Showalter, 1977).

Dominant versions of history either neglect the minimal presence of women, or mention some women who have never disturbed the frames of the assertive -dominant- social order. In nineteenth century Maharashtra, Pandita Ramabai and Tarabai Shinde tried to challenge prominently traditional frames of the privileged patriarchal social order. One of the main agendas of feminist historiography is to counter these dominant versions of women's invisibility explained as women's incapacity to be in the family and the public sphere.

\section{Tarabai Shinde: 'Stree-Purush Tulana'}

Tarabai Shinde was both an activist of the Satyshodhak Samaj2 and a critic of the patriarchal rules imposed by non-Brahmin activists. Most women's writing from the 19th century relating to this subject seems stem from the need to express their pain and struggle and the demand for social justice to improve their deprived status.

Therefore it becomes very important source to understand patriarchal dominance over the society at the time. On this background Tarabai Shinde's text 'Stree-Purush Tulana' is full of expressions of Patriarchal value system imposed by non-Brahmin activists who argued that caste was the main form of social and religious antipathy in Hindu society. In the first paragraph of introduction of her essay she clarifies the purpose of her writings. 'God brought this amazing universe into being, and he it was also who created men and women both. So, is it true that only

\footnotetext{
2 Editor's Note: Satyashodhak Samaj (Truth-seekers' Society) was a social reform society founded by Jyotirao Phule in Pune, Maharashtra, on 24 September 1873. It espoused a mission of education and increased social rights and political access for underprivileged groups, focused especially on women, Shudras, and Dalits, in Maharashtra. Jyotirao's wife Savitribai was the head of women's section of the society.
} 
women's bodies are home to all kinds of wicked vices? Or have men got just the same faults as we find in women?

Stri-Purush Tulana was a critique of gender relations as well as caste, both of which disempowered lower caste women. This presents to point out Tarabai's combat as one of the first feminist critiques on chauvinistic structure of caste.

Tarabai Shinde acknowledged that, a woman also has evil deeds but she is always judged on the basis of vices and not generosity. She argues, "Granted, women are as stupid as buffaloes in the cow pen! They are ignorant and do not grant them even an iota of intelligence? Thoughtless and rash they may sometimes be, but even then they are for preferable to you. Yes! To you who are the bastions of erudition and wisdom! Why, one has only to visit a prison to get proof of this!" (Shinde, 1882). She enquires intensely, that if only women have vices then why the all prison is full of men criminals. She used very persuasive language to describe the condition of women in India. In case of men they are always considered ideal in society, Tarabai said, "Everyone there has a wise head on his shoulders, and a 'wise' deed to his credit!" (Tharu \& Lalita, 1993). Tarabai Shinde claimed that almost all men in colonial period reforms made by British accepted which was had deep concern and beneficial to men, on the contrary essential and required reforms which will help out women to come out through worst social condition and enhance the opportunities for development of women, those denied by men very conveniently. O'Hanlon Rosalind's critical argument on this is:

'It is in this broad context that Tarabai's critique of the politics of gender in colonial society is best understood. As she sees it, men had gained access to a new range of powers under the colonial rule, which they used for their own vanity and self-aggrandizement, even as they tried to shut women out from its benefits and lock them into an ossified 
religious culture for which men themselves now had no regard. She looks at dress, food, travel, new forms of consumption, employment and education that Indian men embraced so enthusiastically, from boots and stockings to pigeon and liquor for supper, from travel by steamship to living in colonial-style bungalows, a rush to embrace British fashions that only made men a laughing stock, yet many of the same men had the effrontery to put themselves forwarded as the champions of an inviolate religious tradition at home' (O'Hanlon, 1994).

Tarabai had discussed in this book nine blames or weaknesses conventionally and traditionally imposed by men since long time. She clarifies the blames and also she states how men are responsible for women's illiteracy, lacking in skill development etc. She also claims that women have all capacities and abilities that men, possess but are suppressed by the patriarchy on purpose. She said, "What's good for a man ought to be good for woman as well". Tarabai Shinde found the privileges enjoyed by men to be cause of the degradation of women. "This is, of course, not to say that all the women in the world are as luminous as the sun and as pure as the waters of the Holy Ganga. But even if one takes into account the entire female community in the world, it would be difficult to come across more than ten percent of them who, like you, are caught in the whirlwind of such insidious perfidies, though not a single one of you is free of them" (Tharu \& Lalita, 1993). There are prejudices about women and they are treated like vultures, facts remain invisible.

\section{Pandita Ramabai: 'The High Caste Hindu Woman'}

Dr. Rachel Bodley rejoices in her introduction to Pandita Ramabai's "The High Caste Hindu Woman: "The silence of a thousand years has been 
broken, and the reader of this unpretending little volume catches the first utterances of the unfamiliar voice throbbing with woe, they are revealed in the following pages to intelligent, educated, happy American women" (Ramabai, 1887). 'The High Caste Hindu Woman', is persuasive narration of the circumscribed and exploited lives of upper-caste Hindu women, which was adjoining outline for their opening of liberation.

During her brief career as a social analyst, Ramabai wrote a work that seeks our attention. 'The High Caste Hindu Woman' (HCHW), presented Indian society to Americans via analytic arguments of the place of women in traditional upper-caste India. Intense and critical, the book yet maintained both Indian national pride and a profound sympathy for the Hindu culture that Ramabai would never lose in front of the presented American society and also to an educated Indian audience. The first edition of ten thousand copies of High Caste Hindu Woman, 1888, was sold out before she left for the United States in 1889 (Tharu \& Lalita, 1993).

After two years of being mentored by Cheltenham's exceptional Dorothea Beale, she went to the United States to attend a countrywoman's graduation of Anadibai Joshi from the Woman's Medical College of Philadelphia. Amazed by the active world of late 19th-century American feminism, she conceived the idea of creating a school for Hindu widows -the child-marriage system guaranteed that there were many of these-. In her new language of English, she quickly wrote The High Caste Hindu Woman as a fund-raising tract. She travelled thousands of miles around the United States, lecturing and organizing "Ramabai Circles," which would contribute the money necessary for her planned school. In her contact with American philanthropists and educators, during the year of her sojourn in the United States, Ramabai has found popular ideas concerning the women of India erroneous, and it is to correct these, 
and also to reveal fully their needs, that the following chapters have been prepared. She has written in the belief that if the depths of the thralldom in which the dwellers in Indian zenanas are held by cruel superstition and social customs were only fathomed, the light and love in American homes, which have so comforted her burdened heart, might flow forth in an overwhelming tide to bless all Indian women. The task of preparing The High-caste Hindu Woman has not been for her a congenial one. She is not by nature an iconoclast. She loves her nation with a pure, strong love (Ramabai, 1887). The book depicts every stage of a high caste woman's life, beginning with 'Childhood', 'Married Life', 'Woman's Place in Religion and Society', 'Widowhood' and last is 'How the Condition of Women Tells upon Society'. At the end of the book she appeals to raise the institution for girls and women who are deprived from education and lacking many opportunities to build their living. Stating a woman's place in religion and society so that Ramabai's comments can be given a clear context and ending with an appeal for the betterment of women's lives through the establishing of an institution where high caste widows could be educated and foster for and taught to be self reliant - this she points out in an earlier chapter is against Manu's laws, since women are never fit for independence (Ramabai, 1887).

Ramabai accepted western arguments for progress and development Indian women's position. She got her funding from America, then. Yet at the same time she has a spirit of an Indian nationalist. She talks about how Indian men are least bothered about women's worst condition; also their failure to help them out and responsibility for the deterioration of Hindu nation. Pandita Ramabai argues that, "Those who have done their best to keep women in a state of complete dependence and ignorance vehemently deny that this has anything to do with the present degradation of Hindu nation" (Ramabai, 1887). Further she reasoned out, a problem 
with Hindu high caste women about, why and how the fail to help their nation: "[Women] They grow to be selfish slaves in their petty individual interests, indifferent to the welfare of their own immediate neighbors, much more to their nation's well-being. How these imprisoned mothers could be expected to bring forth children better than themselves, for as the tree and soil are, so shall fruit be" (Ramabai, 1887). Ramabai does not fire into any kind of rhetoric against society. Very convincingly and logically she points out that women by being unwilling to learn and giving in to slavery will in no way be capable of producing children who will do the nation proud. The sons of such mothers will only learn fault-finding with neighbors, bitter feelings towards tyrant relatives expressed in words and actions, selfish interest in personal and family affairs since that is the only thing that high caste women confined to purdah are allowed to trifled in.

Pandita Ramabai was very empathetic about women's overall position, then. She concludes that the condition of her country women will ever improve without economic self -reliance. After returning from America she opened widow homes in Pune and after in Kedgaon, she made plans to provide vocational training to the girls such as teachers, governess, nurses, home keepers, printing press, farming etc. Pandita Ramabai's own struggle might have persuaded her of the commitment for providing the means of survival of widows. Pandita Ramabai's exposed with critical evaluation and analysis of the customs imposed by patriarchal system in each stage of a woman's life from childhood, married life to widowhood. She argues the evil practices from a historical perspective and pointing out the declination of freedom of women with regard to related social institutions. I would like to close my disposition with Meera Kosambi's analytical perspective of Pandita Ramabai's writings' impact in the Western world. When lent Ramabai's contribution special valence was that it was she - a solitary and largely unsupported Indian woman ....who 
'named' most eloquently and systematically the problems of the 'oppressed Indian woman', so highly toped in the West..... This attempt to trace her entire register is a project of retrieval - of her significant texts, her multiple ideological evolutions and of the intricacies of her feminism within the intersecting and sometimes conflicting structures of patriarchy, religion, nationalism and internationalism (Kosambi, 2016).

\section{Conclusion}

In the first part of the research paper I have tried to clarify the concept of feminism and historiography. My response to this issue has been to handle an investigation into the concept of feminist historiography with help of writings of Pandita Ramabai and Tarabai Shinde. To ensure clarity as we seek to further investigate this is an important model of feminist historiography.

In its essence this effort is to develop an opportunity to create a space and alternative for re-examining the numerous writings by women in history from a different perspective. From a historiographical perspective, it is also essential to explore how feminist histories are being constructed and composed, how genetically relations traced with generations are able or unable to connect with each other. Interesting feminist historiographical possibilities can thereby emerge through engagement with multiple models of social, cultural and economic relations.

Both, Tarabai Shinde and Pandita Ramabai came from distinct cultural set up. That is why I avoided comparing their writings with each other. Most importantly, they criticized patriarchy extensively. Most of the time both of them, wrote critically with contemporary experiences of their own. They have taken into consideration social, religious and political pressures on women. Both were well aware of the colonial 
atmosphere then. So it is stood out in their writings as landmark interpretations.

Despite coming from distinct cultural backgrounds Tarabai Shinde and Pandita Ramabai both criticized patriarchy extensively and their writings were drawn from and represent their personal experiences from the time. 


\section{References}

Browne, V. (2013) Feminist Historiography and the Re conceptualization of Historical Time. Thesis, University of Liverpool.

Chandler, J. (1998) England in 1819: The Politics of Literary Culture and the Case of Romantic Historicism. Chicago, University of Chicago Press.

Kosambi, M. (2016) Pandita Ramabai: Life and landmark writings. Routledge, London and New York.

La Capra, D. (1985) History and Criticism. Cornell University Press, Ithaca and London.

Lerner, G. (1979) The Majority Find its Past: Placing Women in History. New York and Oxford, Oxford University Press.

Millet, K. (1998) Sexual Politics. Indiana Publications, Rome.

Niranjana, S. (1989) Themes of Feminity: Notes on the World of women's Fiction. New Quest.

O'Hanlon, R. (1994) A Comparison Between Women and Men: Tarabai Shinde and The Critique of Gender Relations in Colonial India. Oxford University Press, Madras.

Ramabai, P. (1887) The High Caste Hindu Woman. Rachel L. Bodley, Philadelphia.

Sangari, K. \& Vaid, S. (1986) Recasting Women: Essays in colonial History. New Delhi: Kali for Women.

Shinde, T. (1882). Stri-PurushTulana', Shri Shivaji Chhapkhana, Bulthane, Prant -Varhad.

Showalter, E. (1977) A Literature of Their Own: British Women Novelists from Bronte to Lessing. Princeton: Princeton University Press.

Tharu, S. \& Lalita, K. (1993) Women Writing in India: 600 B.C. to the Early 20th Century. Oxford University Press. New Delhi. 